\title{
IIRTBT WOMEN EMPOWERMENT IN TOURISM AND HOSPITALITY SECTOR IN SAUDI ARABIA
}

\author{
Fardaows Mohamad Alshareef ${ }^{1 *}$, Ali Ahmed AlGassim² \\ ${ }^{1}$ Alrajhi Investment, Makkah, Saudi Arabia \\ ${ }^{2}$ Umm Al-Qura University, Makkah, Saudi Arabia \\ *Corresponding Author's Email: Fardaws1990@gmail.com
}

\begin{abstract}
Women empowerment is an objective of Saudi Arabia's vision 2030, especially in the tourism and hospitality sector. However, little information about women empowerment in the sector is known. To fulfill the gap, this study examined the impact of perception of socioeconomic, perception of gender equality and perception of sociocultural on women empowerment in the tourism and hospitality sector. To check the aim and validity of the study, data were collected from 306 Saudi women employed in the Saudi tourism and hospitality sector through an online survey. The data were analyzed applying factor analyses, Cronbach's alpha, comparative means, standard deviation, Mann-Whitney Test and Kruskal-Wallis test. Women believe that there are some jobs that are more appropriate for women than men. Women will not be given equal employment opportunities and privileges men receive as well as they have a moderate belief that they are given their right to supervisory and administrative positions as men are given. The respondents think that undesirable attitudes regarding Saudi women's empowerment in the tourism and hospitality sector will be changed and undermine soon. Also, they think that working in the sector has a moderate negative impact on women's health and family obligations, such as taking care of their children. Finally, respondents revealed that women are not given the same respect men receive and the salary paid to women is unfair compared to men. In addition, women are not given the right to make decisions as men are given.
\end{abstract}

\section{Keywords: Women Empowerment; Tourism and Hospitality Sector; Perception of Socioeconomic;} Perception of Gender Equality; Perception of Sociocultural

\section{INTRODUCTION}

Tourism provides significant opportunities for women internationally. Over the past two decades, there has been intense debate about women empowerment in the different communities' transformations (Cornwall \& Rivas, 2015). All countries within the United Nations especially the developed ones have specified women empowerment as central to their peaceful and sustainable development (Cornwall \& Rivas, 2015). Currently in Saudi Arabia women empowerment has been the most controversial topic (Alsubaie \& Jones, 2017). Female participation in the Saudi workforce has long been low due to cultural and societal reasons (AlQahtani et al. 2021). From the 1960s onwards, Saudi politics and reforms have come a long way for empowering Saudi women in many sectors. Recently, the King Abdullah scholarship program has accelerated this effort in the education sector, which has resulted in more Saudi women obtaining higher education, constructing more universities, and offering educational scholarships abroad.

Despite working for public and the private sectors require women participation, the role of women in the workplace and management is constrained and policies and regulations that protect them are limited (Ballakrishnen et al. 2019; Elamin \& Omair, 2010). Hence, women compared to other Gulf countries Saudi women comprise a small percentage of the Saudi workforce. Recently, the entry of Saudi women into the workforce increased from $20 \%$ in 2018 to $33 \%$ by the end of 2020 which means that the share of Saudi women in the workforce increased by $64 \%$ in only two years (Tamayo, Koettl \& Rivera, 2021). The low proportion of women's participation in the labor market is because of the isolation between male and female and the roles of work are basically defined by their situations (Elamin \& Omair, 2010).

Further, women's participation and work roles in the work environment is affected by the culture, costumes, and their tribal traditions (Elamin \& Omair, 2010). For instance, such cultural impact is the community's belief that a Saudi women's working may bring disgrace on family since her need to work reveals that close family or her extended tribe that they are unable to financially support her. Hence, due to these social-cultural effects, employers sometimes avoid employing women in their 
companies (Omair, 2009). Consequently, women entering the workforce environment, such as hotels and restaurants, is low (Marmenout \& Lirio, 2014), particularly with the limitation of jobs that are suitable and required by Saudi women and their families. Until a few years ago, the isolation of women has meant that women prefer to work in environments that are conventionally held by women, such as teaching (AlQahtani et al. 2020), nursing, and banking sector. Indeed, the main reason behind the low participation rate of women in other sectors is not because lack of interest; instead, due to a shortage in job opportunities, cultural issues, and regulations.

In 2018, the World Bank indicated that there is considerable growth in the number of women entering the sector. The contribution rate of Saudi women increased from $20 \%$ in late 2018 to $33 \%$ by the end of 2020 which means the share of women in the workforce increased by an enormous $64 \%$ in just two years (Tamayo, Koettl \& Rivera, 2021). However, in the managerial positions are less than $40 \%$. Meanwhile, members of Boards of Directors only $5 \%$ to $8 \%$ (Baum $\&$ Cheung, 2015). Therefore, the increase of women participation in workplace is one of the priorities for the Saudi government. The growth of employment opportunities in the hospitality and tourism sector in the Kingdom between 2010 and 2020 is estimated at 10\% annually compared to the global growth rates for the same period, which was estimated at $2.5 \%$ annually. The number of direct jobs in tourism sector is 552.556 in 2018, (Ministry of Tourism, 2020) the percentage of Saudi employment in the sector is $22.3 \%$ which is 123.219 employees. The number of females is 27.108 employees which is almost $22 \%$ of total jobs for Saudis. The Saudi women's contribution rate of the labor force increased from $20 \%$ in late 2018 to $33 \%$ in 2020 which means that the Saudi women in the workforce grew by an incredible $64 \%$ in just two years (Tamayo, Koettl \& Rivera, 2021). The Ministry of Tourism is targeting to raise the contribution of Saudi women in the labor market associated with the tourism sector from $22 \%$ to $30 \%$ by 2030 .

Despite the domination of Saudi women's empowerment perspectives, constantly emphasize the underrepresentation of women in different sectors in Saudi Arabia. Newly, there are some improvements in women's presentation in all fields of economy (Alsubaie \& Jones, 2017). However, not much is known about women empowerment, mainly in the environment of the hospitality and tourism sector in Saudi Arabia. Further, there is no study about Saudi women empowerment obstacles and community role in women empowerment Nevertheless, many challenges are confronting women empowerment in the sector, which need to be investigated. Hence, the current study aims to understand, from the perspective of women working in the sector, the challenges and factors that affect their participation and empowerment in the sector. Further, due to Saudi women recently has entered the sector, this study aims to understand how the sector treat women and if there are inequality practices from the sector leaders against them.

\section{LITERATURE REVIEW}

Empowerment has experienced decades of development to conform different disciplines, such as psychology, sociology, and tourism studies (Movono \& Dahles, 2017). Due to the differences and the underlying implications of the term, there is no consensus reached about the nature definition of empowerment (Pelit, Öztürk \& Arslantürk, 2011). In the English language, the root of the word "Empowerment" is "Power" which means having control over things (Lincoln et al. 2002). The verb "empowers", as defined by the Oxford English Dictionary, means "to enable" (Jay \& Rabindra, 1988). Power was defined as having two control aspects: resources, such as physical, human, and belief, such as values and attitudes. Hence, empowerment means obtaining control, if power means to control (Cornwall, 2016). Empowerment is defined as a process of helping individuals to recognize themselves and their competencies and abilities to enhance their quality of choices and make strategic decisions in their lives (Zimmerman, 2000). Oxaal \& Baden (1997) and Dashti \& Mesbah (2016) said that empowerment happens when individuals are enabled to participate in the decision-making process which considers the main component of empowerment.

Women empowerment may occur when she has gained an educational certificate, obtaining legal or political rights that are equal or nearly equivalent to male (Dashti $\&$ Mesbah, 2016). Women power or empowerment is not about fighting to take power from men; instead, their goal should be on developing their own power by respecting men as they are (Lincoln et al. 2002). Women empowerment is when she becomes able to expand her own self-dependence, to be autonomous to decide and to manage resources (Alsawafi, 2016). However, empowerment will require cultural, economic, and political changes (Cornwall, 2016).

\section{Gender Equality}

Studies of gender equality in tourism research started in 
the early 1980s and become coherent in the mid-1990. Internationally, there are number of agreements exist to ensure gender equality and women empowerment (Ferguson, 2018). Gender mainstreaming is a strategy that is accepted for achieving these objectives, and to confirm that gender standpoints and concern to the objective of gender equality are focal to all actions that include: developing policy, research and studies, legislation, and planning (Ferguson, 2018).

Equality of gender means having the same treatment for both men and women have in the workplace concerning rights, benefits, commitments, and promotion opportunities. Equality of gender is also referring to a social status whereby men and women obtain the same rights and power, condition, and opportunities. Moreover, gender equality can be obtained by women and men having (1) an equal access to all resources; (2) equal participation in relationships, community, family, and political rights; and (3) safety or freedom from violence.

However, tourism has shown reluctance to gender mainstreaming. Tourism research on gender equality showed that there is no agreement in terms of the policy statement (Ferguson, 2018). Further, most international organizations, such as United Nations World Tourism Organization have no guidelines, policies, or programs on practicing gender equality in tourism organizations. In addition, only a few countries have developed policies concerning gender equality in tourism, such as Mexico and Nicaragua (Ferguson, 2018).

To minimize gender inequality is by educating society about the negativity that inequality can do to women and their workplace, which will then correct or ameliorate their own and others' prejudice against women (Chang \& Milkman, 2020). It was confirmed that organization with more women in the directors' boards has higher average returns on equity and better growth.

Often in the workplace when different genders in the same position or level receive equal benefits create hostilities (Ruohan \& Xueyu, 2016). For instance, when a woman has many men colleagues' surroundings her, it may cause an inconvenient and unsatisfactory work environment to her. Further, many men who supervise women may make obstacles or delay in promotions for those women for their benefits (Inglehart \& Norris, 2003). Nevertheless, the equal gender distribution of benefits in the work environment delivers more satisfaction and competence that ensures a healthy career path and then improves workers' effectiveness (Ruohan \& Xueyu, 2016). Hence, enforcing equality of gender is conventionally an important aspect of success for any business (Inglehart \& Norris, 2003).

\section{Women Empowerment in Saudi Workforce}

Woman is a major part of several reform movements of the 21 st century. These reform movements sought to promote basic changes in Saudi society, and female political involvement includes providing an equal opportunity to women, which is one of the Saudi 2030 vision pillars. Women empowerment has been the most controversial topic currently in Saudi Arabia because increase of women's participation in the workplace is one of the priorities for the Saudi government. Therefore, in both public and private sectors, Saudi women witnessed some increase in their participation in managerial positions as well as in decision-making (Aldakhel, 2019).

Saudi women were able to work within limited areas that include teaching, banking, and nursing, while other areas were restricted for women because they are dominated by men. There are three conditions that allow women to work: (1) not to neglect her family member, such as husband and children; (2) she works only if there is no direct contact with strange men; and (3) she works in jobs that suits her female nature. However, most Saudi women with about $62 \%$ are working in the teaching sector because of segregation of gender where female is only taught by another female.

Workplace participation, according to the United Nation, that in Saudi Arabia in 2018 female participation in the labor market is $23.4 \%$ compared to $79.2 \%$ for men (OECD, 2019). Saudi Arabia undertakes continuing support for women's participation in the workforce up to $30 \%$ by 2030 (OECD, 2019). Recently, Saudi women broke the stereotype, they participated in professions they have never worked before, such as hotels and restaurants, passport control, retails shops, cashiering in shopping, waitresses (Almadani, 2018). The contribution of women in the business workforce made an important change in the conventional role of women in Saudi Arabia (Elamin \& Omair, 2010). The desire that Saudi women have to become financially independent and have self-recognition has increased amongst educated women and facilitate the way for them to join the workforce.

\section{Women Empowerment in the Saudi Hospitality and Tourism Sector}

The tourism sector is one of the most growing sectors in Saudi Arabia. According to the 2030 vision, the Saudi government is giving unlimited support to this 
important sector. This sector will create thousands of jobs by the year 2030 as per the Minister of Tourism (Ministry of Tourism, 2020). The growth of employment opportunities in the hospitality and tourism sector in Saudi Arabia between 2010 and 2020 is estimated at $10 \%$ annually compared to the global growth rates for the same period, which was estimated at $2.5 \%$ annually.

One of 2030 vision goals is to enhance the contribution of Saudi women in the labor market associated with the tourism sector from $22 \%$ to $30 \%$ by 2030 . They created qualified programs for hospitality and tourism workers and students around the Kingdom. Around 8,108 Saudi male and female have been graduated from tourism institutes in addition to 405 women certified tourist guides (Saudi Gazette, 2019). Locally the ministry targeting to increase the number of beneficiaries up to 25,000 female trainees and 1,400 women certified tourist guides by the end of 2020 .

However, the opportunity in the sector is still limited for Saudi women. She still mainly performs jobs at the entry-level, such as telephone operator, customer service, order taker, host, and receptionist. The number of Saudi women with considerable experience and effective networking is countable. There is high turnover in the sector which means start-over in a different company with the same position (Alferaih, 2017). Also, job opportunity is seasonal and fluctuates or short time contract with renewal due to the nature of the industry which mean not secured job.

Before joining the industry, a woman usually has to convince her family to study or work in the hospitality and tourism sector. The family support and trust are a strong factor of joining the sector. The women's work decision, religion and tradition are the most important factors to join the sector (Alsawafi, 2016). In terms of challenges preventing Saudi women to join the tourism and hospitality sector can be summarized as follows; the negative community prospective, family misunderstanding, low salary, different shifts "AM, PM and Night", "may need to work during holidays and weekend (Alsawafi, 2016).

\section{RESEARCH METHODOLOGY}

The current study aims to obtain information regarding Saudi women in the hospitality sector regarding their perception of empowerment on the study factors namely, "socioeconomic, gender equality, and sociocultural" in the hospitality sector. The data were collected from the Saudi women employed in the tourism and hospitality sector. The results of this research will enhance the research and give implications to assist leaders in this sector regarding improving Saudi women empowerment strategies, policies, and regulations.

Primarily, the researchers of this study implemented a questionnaire created by (Alsawafi, 2016; Dashti \& Mesbah, 2016), with modifications, such as adjusting, deleting, and expanding items as per the outcome from the interviews to be finally ( 30 items). The items are also found from the literature review concerning Saudi female empowerment and gender equality in the sector. Moreover, to build the current survey, phone calls and online interviews were performed with the experts and scholars in the sector. The study developed 30 items grouped into three dimensions, namely, perception of socioeconomic (14 items), Perception of gender equality (4 items), and Perception of sociocultural (12 items), Demographic is (4 items). The study further applied the Likert 5-point rating scale, ranging from strongly agree (5) to strongly disagree (1) to measure the items.

\section{Data Collection and Analyses}

The focus group of this study is the Saudi women employed in the tourism and hospitality sector to measure women empowerment in the sector. An electronic survey was conducted between May and August 2020, and the survey was distributed among female employees working in all different tourism and hospitality sectors; however, most of the survey comes from the hotel industry. The data was collected during health quarantine caused by Covid-19. The authors received 306 electronic valid questionnaires from Saudi women. For data analysis, factor analysis, mean comparison, and standard deviation, ANOVA test is used.

To confirm the dimensions' validity, factor analysis with varimax rotation is performed to detect the loading factor of the 30 items. After completing the analysis, the researchers noticed that all items were entirely loaded into three dimensions as presented above. Finding's evidence and validate that the three dimensions extract and generalize item data and are highly explorative and valid. Furthermore, Cronbach's alpha value for the three factors is 0.757 , confirming its reliability.

The electronic survey was completed by 306 women that representing $100 \%$ of the sample. The years of experience varied from one year to 21 years. The highest rate of respondents $40.8 \%$ of the sample was a range between 1 and 3 years of experience. Most of the women, who filled in the survey, have a college or 
university degree, which represented $76.5 \%$. Job level represented $39.5 \%$ of the sample is non-managerial level and $11.8 \%$ of the sample are in high managerial level. All the respondents have Saudi nationality.

\section{Perception of Socioeconomic}

The findings show that Saudi women have a rational view toward the socioeconomic in the sector with a high mean (4.12). Table 1 highlights that item 4 has the maximum with a mean (4.55), where Saudi tourism and hospitality sector is more likely to be the creature of job for Saudi women; followed by item 9 that certain jobs in the sector are more appropriate for women than men with a mean (4.37). Item 2 shows that women employed in the sector agree that the current economic crises require the female contribution with a mean (4.21). Furthermore, item 5 highlights that the negative views about Saudi women's empowerment will transform and be weaken in the future with a mean (4.20). Also, item 6 represents that the Saudi women in the sector strongly support their empowerment if there is no religious ban alongside their empowerment with a mean (4.30).

Table 1: Factor Analyses and Mean Comparisons

\begin{tabular}{|c|c|c|c|c|c|c|}
\hline \multirow{2}{*}{\multicolumn{2}{|c|}{ Items of Hypothetic Dimensions }} & \multicolumn{3}{|c|}{ Factor Analyses } & \multirow{4}{*}{$\begin{array}{l}\text { Mean } \\
4.02\end{array}$} & \multirow{4}{*}{$\begin{array}{l}\text { S. D. } \\
1.07\end{array}$} \\
\hline & & \multirow[t]{2}{*}{1} & \multirow[t]{2}{*}{2} & \multirow{2}{*}{3} & & \\
\hline \multicolumn{2}{|c|}{ Perception of socioeconomic $(\alpha=0.85)$} & & & & & \\
\hline 1 & $\begin{array}{l}\text { There is a lots of job opportunities for women in the tourism and } \\
\text { hospitality sector in Saudi Arabia for Saudi women }\end{array}$ & 0.42 & & & & \\
\hline 2 & $\begin{array}{l}\text { Women through increasing their participation in Saudi Arabia tourism } \\
\text { and hospitality sector. The current economic crisis requires the } \\
\text { contribution of Saudi women }\end{array}$ & 0.61 & & & 4.21 & 1.08 \\
\hline 3 & $\begin{array}{l}\text { There is a real need for Saudi women's empowerment in the tourism } \\
\text { and hospitality sector in Saudi Arabia }\end{array}$ & 0.27 & & & 3.83 & 1.29 \\
\hline 4 & $\begin{array}{l}\text { The Saudi tourism and hospitality sector is expected to be the main } \\
\text { source of job creation for Saudi Women in the future }\end{array}$ & 0.72 & & & 4.55 & 0.86 \\
\hline 5 & $\begin{array}{l}\text { The negative attitudes towards Saudi women's empowerment in the } \\
\text { tourism and hospitality sector will change and weaken in the future }\end{array}$ & 0.75 & & & 4.20 & 0.98 \\
\hline 6 & $\begin{array}{l}\text { I support Saudi women's empowerment in the tourism and hospitality } \\
\text { sector if there is no religious prohibition against their empowerment in } \\
\text { the sector in general or in a specific job in particular }\end{array}$ & 0.53 & & & 4.30 & 0.90 \\
\hline 7 & $\begin{array}{l}\text { Saudi women working in public tourism and hospitality sector is more } \\
\text { acceptable than their working in private tourism and hospitality sector }\end{array}$ & 0.56 & & & 3.99 & 1.08 \\
\hline 8 & $\begin{array}{l}\text { The Saudi government plays an efficient role to change the negative } \\
\text { attitudes towards Saudi women's empowerment in the tourism and } \\
\text { hospitality sector }\end{array}$ & 0.78 & & & 4.33 & 0.99 \\
\hline 9 & $\begin{array}{l}\text { Certain jobs in the tourism and hospitality sector are more suitable for } \\
\text { women than men }\end{array}$ & 0.79 & & & 4.37 & 0.94 \\
\hline 10 & $\begin{array}{l}\text { In general, there is resistance within Saudi society to Saudi women's } \\
\text { empowerment in the tourism and hospitality sector }\end{array}$ & 0.50 & & & 3.83 & 1.16 \\
\hline 11 & $\begin{array}{l}\text { The society's negative attitude towards Saudi Women empowerment } \\
\text { in the tourism and hospitality sector is unjustified }\end{array}$ & 0.67 & & & 4.12 & 1.13 \\
\hline 12 & $\begin{array}{l}\text { Saudi women's empowerment in the tourism and hospitality sector } \\
\text { does not differ from their empowerment in other sectors, such as } \\
\text { education or health sectors }\end{array}$ & 0.70 & & & 4.06 & 1.02 \\
\hline 13 & $\begin{array}{l}\text { Saudi women prefer to work on a temporary basis in the tourism and } \\
\text { hospitality sector until they get government jobs }\end{array}$ & 0.27 & & & 3.73 & 1.01 \\
\hline 14 & $\begin{array}{l}\text { Saudi women's empowerment in the tourism and hospitality sector } \\
\text { impacts negatively on their family responsibilities, such as raising } \\
\text { children }\end{array}$ & 0.78 & & & 3.40 & 1.31 \\
\hline
\end{tabular}


Similarly, item 8 shows that Saudi women strongly believe that the government plays an effective part to change the negative views about women's empowerment in the sector with a mean (4.33). However, item 14 that is Saudi women's empowerment in the sector negatively influences their family's accountabilities, such as taking care of their children, which scored the lowest with a mean (3.40); followed by item 13 where Saudi women favor finding a job on a temporary basis in the sector until they get government jobs with a mean (3.73).

\section{Perceived Gender Equality}

Findings in table 2 indicate that the tourism and hospitality sector is almost moderate for the perceived gender equality dimension with a mean (3.12). The highest response is for item 17 where Saudi woman do not highly believe that in the tourism and hospitality sector are not given their right to supervisory and administrative positions as men are given with mean (3.58).

Table 2: Factor Analyses and Mean Comparisons

\begin{tabular}{|l|l|l|l|l|l|l|}
\hline \multicolumn{2}{|l|}{ Items of Hypothetic Dimensions } & Factor Analyses & \multirow{2}{*}{ Mean } & SD \\
\cline { 2 - 3 } & $\mathbf{1}$ & $\mathbf{2}$ & $\mathbf{3}$ & & & \\
\hline 15 & $\begin{array}{l}\text { Saudi women are given equal employment opportunities by the tourism and } \\
\text { hospitality sector. }\end{array}$ & 0.77 & & 2.87 & 1.33 \\
\hline 16 & $\begin{array}{l}\text { Saudi women are given the same privileges men receive in tourism and } \\
\text { hospitality sector }\end{array}$ & 0.78 & & 2.90 & 1.28 \\
\hline 17 & $\begin{array}{l}\text { Saudi women in the tourism and hospitality sector are not given their right } \\
\text { to supervisory and administrative positions as men are given }\end{array}$ & 0.63 & & 3.58 & 1.26 \\
\hline 18 & $\begin{array}{l}\text { Working for the tourism and hospitality sector has a negative impact on } \\
\text { women health }\end{array}$ & 0.43 & & 3.31 & 1.05 \\
\hline
\end{tabular}

Also, item 18 reveals that Saudi women do not highly believe that working for the tourism and hospitality sector has a negative impact on their health as indicated with the mean (3.31). Nevertheless, surprisingly, respondents show in item 15 and item 16 below moderate about wither Saudi women are given the same privileges men receive and equal employment opportunities in tourism and hospitality with a mean (2.87 and 2.90) respectively.

\section{Perception of Sociocultural}

Results in table 3 show that women in the tourism and hospitality sector have a low perception of sociocultural with a mean (2.85). Item 20 highlights that Saudi women highly believe that society may accept to employ nonSaudi in the tourism and hospitality sector if there is a need to employ females with a mean (4.45). Unexpectedly, respondents scored slightly low for item 19 that women can be employed in the sector if there is no prejudice to the traditions of the Saudi society and item 26 where women in the tourism and hospitality sector are not given the right to make decisions as men are given with mean (3.68 and 3.74) respectively.
Further, respondents scored close to moderate for item 28 and item 30 that the companies in the sector do not consider the differences between gender and do not separate tasks and working for the sector negatively impact my social relations with a mean (3.28 and 3.12) respectively. Item 25 reveals that Saudi women moderately believe that salary in the sector is inequal compared to the salary of male colleagues with a mean (3.43).

Surprisingly, the findings in table 3 reveal that the women scored low for item 23 and item 29 that many people look down on Saudi women who are employed in the tourism and hospitality sector and the sector requires the presence of Saudi women within its cadres with a mean (2.16 and 2.19) respectively. Further, respondents scored low for item 24 that there are real incentives that encourage Saudi women to work in the tourism and hospitality sector with a mean (2.38). In addition, Saudi scored below moderate for items 21 and 22 those women in the tourism and hospitality sector are given the same respect men get at work and the work environment for Saudi female in the tourism and hospitality sector is inappropriate with a mean (2.60 and 2.64) respectively. 
Table 3: Factor Analyses and Mean Comparisons

\begin{tabular}{|c|c|c|c|c|c|c|}
\hline \multirow{2}{*}{\multicolumn{2}{|c|}{ Items of Hypothetic Dimensions }} & \multicolumn{3}{|c|}{ Factor Analyses } & \multirow[t]{2}{*}{ Mean } & \multirow[t]{2}{*}{ SD } \\
\hline & & 1 & 2 & 3 & & \\
\hline \multicolumn{5}{|c|}{ Perception of sociocultural $(\alpha=0.74)$} & & \\
\hline 19 & $\begin{array}{l}\text { Saudi women can work in the tourism and hospitality sector without } \\
\text { prejudice to the traditions and customs of the Saudi conservative society }\end{array}$ & & & 0.43 & 3.68 & 1.24 \\
\hline 20 & $\begin{array}{l}\text { It is more acceptable in the society to employ non -Saudi women in the } \\
\text { tourism and hospitality sector if there is a need to employ women }\end{array}$ & & & 0.47 & 4.45 & 1.15 \\
\hline 21 & $\begin{array}{l}\text { Saudi women in the tourism and hospitality sector are given the same } \\
\text { respect men get at work }\end{array}$ & & & 0.65 & 2.60 & 1.31 \\
\hline 22 & $\begin{array}{l}\text { The work environment for Saudi female in the tourism and hospitality } \\
\text { sector is inappropriate }\end{array}$ & & & 0.47 & 2.64 & 1.39 \\
\hline 23 & $\begin{array}{l}\text { Many people look down on Saudi females who work in the } \\
\text { tourism/hospitality sector }\end{array}$ & & & 0.70 & 2.16 & 1.26 \\
\hline 24 & $\begin{array}{l}\text { There are real incentives that encourage Saudi women to work in the } \\
\text { tourism and hospitality sector }\end{array}$ & & & 0.69 & 2.38 & 1.30 \\
\hline 25 & $\begin{array}{l}\text { A Saudi woman's salary in tourism and hospitality sector is unfair } \\
\text { compared to the salary of male colleagues }\end{array}$ & & & 0.31 & 3.43 & 1.29 \\
\hline 26 & $\begin{array}{l}\text { Saudi women in the tourism and hospitality sector are not given the right } \\
\text { to make decisions as men are given }\end{array}$ & & & 0.34 & 3.74 & 1.29 \\
\hline 27 & $\begin{array}{l}\text { Tourism companies do not consider the physical and social conditions of } \\
\text { females when giving them assignments }\end{array}$ & & & 0.42 & 3.58 & 1.32 \\
\hline 28 & $\begin{array}{l}\text { Most tourism and hospitality companies do not consider the differences } \\
\text { between men and women and do not separate tasks between the sexes }\end{array}$ & & & 0.19 & 3.28 & 1.30 \\
\hline 29 & $\begin{array}{l}\text { The nature of tourism and hospitality sector in Saudi Arabia requires the } \\
\text { presence of Saudi women within its cadres }\end{array}$ & & & 0.600 & 2.19 & 1.25 \\
\hline 30 & $\begin{array}{l}\text { Working for the tourism and hospitality sector negatively affects my } \\
\text { social relations }\end{array}$ & & & 0.49 & 3.12 & 1.26 \\
\hline
\end{tabular}

\section{RESULT \& DISCUSSION}

Women empowerment is one of the main reform plans and goals of Saudi Arabia's vision 2030. The contribution of women in the world workforce has increased in recent years, and women's job opportunities became one of the focuses in Saudi Arabia (Najia, Priyanka \& Saima, 2016). Five years ago, Saudi women were not allowed to work in hospitality companies because most Saudi families look down on such a sector. Before joining the industry, she must convince her family to study or work in hospitality and tourism. The family support and trust are a very strong factor of joining the sector. Education and healthcare are the top best work for women from the family perspective. Saudi government aims to enhance women empowerment to the leadership position in public and private sectors. The Saudi government also forces companies in the tourism and hospitality sector to employ women in all departments. Now Saudi women in the sector now constitute $22 \%$ of the total employment (Ministry of Tourism, 2020). However, as per researcher knowledge, there is no study has been conducted to investigate how women working in the sector feel about their empowerment compared to men in the same sector. Saudi government since the announcement of vision 2030 put the tourism and hospitality sector as one of the main pillars for the development. The government announced many giga projects, such as Neom, Red Sea, Qiddiya, and Amaala.

Hence, respondents believe that the sector is expected to be the main source of job creation for Saudi Women in the future as well as the source for leadership positions, and in the sector, there are certain jobs in the tourism and hospitality sector that are more suitable for women than men. However, despite the government support for women employment in the sector, women do not believe 
that they will be given equal employment opportunities and privileges men receive in the tourism and hospitality sector as well as they have a moderate belief that they are given their right to supervisory and administrative positions as men are given. The absence of gender balance in senior levels still exists in most of the properties in Saudi Arabia. This finding is perhaps because of two reasons; first, the sector is still new for Saudis in general and women in particular; and therefore, women have little experience compared to Saudi men. Second, Saudi Arabia is a conservative society, and many Saudi families believe that women should not be mingled with men in the workplace, and the main job for women is to stay at home, upbringing children, and take care of men whose main responsibly is to work and bring money.

Although the society has many of these extremist families, women working in the public tourism and hospitality sector, such as the Ministry of Tourism are more acceptable for these families than women working in private tourism and hospitality sector. Nevertheless, the respondents believe that the resistance within Saudi society to Saudi women's empowerment and working in the sector is improving day after day and the resistance is much lower than years ago. Therefore, the respondents support Saudi women's empowerment in the tourism and hospitality sector if there is no religious prohibition and prejudice to the traditions and customs of the Saudi conservative society against their empowerment.

Further, the respondents think that the negative attitudes towards Saudi women's empowerment in the tourism and hospitality sector will change and weaken in the future. These findings consist of (Al-Qahtani et al. 2020). The change in the Saudi families' mindset perhaps refers to two reasons. First, Saudi society, in general, became more educated and more aware about the importance of women involvement in the workplace, especially with the high population of women in the society and a significant shortage of job opportunities in the public sectors where women used to work for, such as education and health sector. Second, the Saudi government in the last few years issued number of regulations that protect women in the workforce, those regulations increased the trust of families in the workforce environments. Hence, respondents deem that the society's negative attitude towards Saudi women's empowerment in the sector is unjustified, and the Saudi government should play an efficient role to change the negative attitudes towards Saudi women's empowerment in the tourism and hospitality sector.

Despite working in hospitality needs energy and time because most of the employees spend an average of nine hours a day at work, and sometimes they are required to stay longer hours especially in high seasons. Nevertheless, Saudi women think that working in the sector has a moderate negative impact on their health and on their family responsibilities, such as raising children. These beliefs probably emerged from the changes occurring in Saudi society in general and in the perception of gender equality. Many Saudi youths start to believe that family responsibilities, such as cooking, raising children, and even living expenses are the responsibility of both males and females.

A high number of the respondents agree that it is more acceptable in society to employ non-Saudi in the tourism and hospitality sector if there is a need to employ females. Most employees' males and females who are working in the sector are non-Saudi. The dependence on non-Saudi maybe because most investors in the sector do not trust Saudi employees, non-Saudi receive lower salary and they stay longer working hours if required without overtime pay especially those at entry-level. Therefore, the Ministry of Tourism has launched several specialized programs to rehabilitate, train and raise the awareness of workers and those willing to join the tourism sector, which would support efforts aimed at localizing the tourism and hospitality sector. This effort helped to change the perception of Saudi society toward the women working or aim to work in the sector as respondents thank that society does not look down on women in the sector. Despite all the above challenges, a high number of Saudi women have a strong desire to join the sector and take it as a career that is clearly seen in the number of female $(9,631)$ attended the training programs in 2020.

Women working in the sector believe that there are inequality practices between men and women. Many the respondent revealed that women are not given the same respect men receive and the salary paid to women is unfair compared to men. In addition, women are not given the right to make decisions as men are given. Inequality practices in the sector against women refer to many reasons. First, women have just recently were allowed to work in the sector especially at the entrylevel but not at the managerial level; hence, employers have little trust in their capability and experience. Second, Saudi society is like most eastern societies are male society where men have always the privilege over women especially in the workforce; hence, men are 
allowing preferred for positions over women. Third, it is possible that the employer thinks that Saudi women are dependent on their family or husband, and they do not have much responsibility for their families compared to men; hence, financially they are not in need of high salaries than men do. Finally, there is no rolls and regulation issued by the government to protect women in such in equal cases.

Research on organisations presented those advantages including differences in gender wage, discrimination on age, increase employees' equality, work, and life balance as well as overall organization outcomes (Baum \& Cheung, 2015). Nevertheless, practicing gender equality approach brings external advantage, such as high quality and flexibility of customer service and increase the positive image of the organization (Baum \& Cheung, 2015).

\section{CONCLUSION}

This study has several managerial implications that help to improve women empowerment in the tourism and hospitality sector. First, the Saudi authorities represented by Ministry of Human Resources and Ministry of Tourism is to develop policies and regulations that assist women not only to enter the sector but to be able to work in managerial and executive positions if she is qualified. Further, Saudi authorities need to develop strict regulations that reduce inequality practices and protect women working in the sector. These regulations will also increase women's trust and satisfaction that in turn reduce their turnover. Second, since Saudi women have recently started working in the sector, Saudi authorities need to develop advanced training programs that increase the knowledge and skills of women in the sector, which allow them to take a managerial position soon. Finally, Saudi authorities need to keep aware Saudi youth especially women from the studying and working in the sector, especially with many job opportunities offer for them now and in the future.

\section{Limitations}

This study has several limitations that offer opportunities for future research. First, this study was conducted during the first period of the Covid-19 pandemic which affected the recruitment process of respondents and data collection. As a result, the data was collected through an online survey because at that time most of the tourism and hospitality companies were closed for quarantine. Therefore, the results of this study may be the basis for research involving a larger number of respondents that use face-to-face qualitative data and hard copy questionnaire. Obtaining accurate data about Saudi women perception of empowerment in the tourism and hospitality sector will help to formulate strategies to empower Saudi women to work without discrimination.

\section{Conflict of Interests}

The authors declare that they have no conflict of interests.

\section{ACKNOWLEDGEMENT}

The authors would like to thank Ms. Mona Saigh, Raghad Abdulaziz Alamri and Lamya Barazi for their kind support and contribution to develop this paper.

\section{REFERENCES}

Aldakhel, K. K. (2019, April 28). Saudi Women Proceed with Ambition and Empowerment within the Framework of Vision 2030. Saudi Press Agency (SPA).https://www.spa.gov.sa/viewfullstory.php?la ng=en\&newsid=1917968

Alferaih, A. (2017). Developing a Conceptual Model to Measure Talent's Turnover Intention in Tourism Organisations of Saudi Arabia. International Journal of Organizational Analysis, 25(1), 2-23.

Almadani, T. (2018, June 17). New Options Spur Saudi Women to Join Workforce. Arabnews.com. https://www.arabnews.com/node/1411001/saudiarabia

Al-Qahtani, A. M., Elgzar, W. T., Ibrahim, H. A., ElHoufy, A., \& Sayed, H. A. E. (2021). Women Empowerment among Academic and Administrative Staff in Saudi Universities: A CrossSectional Study. African Journal of Reproductive Health, 25(1S), 60-68.

Al-Qahtani, M. M. Z., Alkhateeb, T. T. Y., Mahmood, H., Abdalla, M. A. Z., \& Qaralleh, T. J. O. T. (2020). The Role of the Academic and Political Empowerment of Women in Economic, Social and Managerial Empowerment: The Case of Saudi Arabia. Economies, 8(2), 45.

Alsawafi, A. M. (2016). Exploring the challenges and perceptions of Al Rustaq College of Applied Sciences Students towards Omani Women's Empowerment in the Tourism Sector. Tourism Management Perspectives, 20, 246-250.

Alsubaie, A., \& Jones, K. (2017). An Overview of the Current State of Women's Leadership in Higher Education in Saudi Arabia and a Proposal for Future Research Directions. Administrative 
Sciences, 7(4), 36.

Ballakrishnen, S., Fielding-Singh, P., \& Magliozzi, D. (2019). Intentional invisibility: Professional women and the navigation of workplace constraints. Sociological Perspectives, 62(1), 23-41.

Baum, T., \& Cheung, C. (2015). White paper women in tourism \& hospitality: Unlocking the potential in the talent pool. In Women in Tourism and Hospitality Forum in Hong Kong, Diageo.

Chang, E. H., \& Milkman, K. L. (2020). Improving Decisions that Affect Gender Equality in the Workplace. Organizational Dynamics, 49(1), 100709.

Cornwall, A. (2016). Women's Empowerment: What Works? Journal of International Development, 28(3), 342-359.

Cornwall, A., \& Rivas, A.-M. (2015). From 'Gender Equality and 'Women's Empowerment' to Global Justice: Reclaiming a Transformative Agenda for Gender and Development. Third World Quarterly, 36(2), 396-415.

Dashti, A. A., \& Mesbah, H. (2016). The Perceptions of Female Media Professionals in Kuwait About Their Job: An Empowerment Perspective. Feminist Media Studies, 16(2), 276-292.

Elamin, A. M., \& Omair, K. (2010). Males' Attitudes towards Working Females in Saudi Arabia. Personnel Review, 39(6), 746-766.

Ferguson, L. (2018). Gender equality and tourism: The global policy context. Gender equality and tourism: Beyondempowerment, 14-22.

Inglehart, R., Norris, P., \& Ronald, I. (2003). Rising tide: Gender equality and cultural change around the world. Cambridge University Press.

Jay, A. C., \& Rabindra, N. K. (1988). The Empowerment Process: Integrating Theory and Practice. The Academy of Management Review, 13(3), 471-482.

Lincoln, N. D., Travers, C., Ackers, P., \& Wilkinson, A. (2002). The meaning of empowerment: The interdisciplinary etymology of a new management concept. International Journal of Management Reviews, 4(3), 271-290.

Marmenout, K., \& Lirio, P. (2014). Local Female Talent Retention in the Gulf: Emirati Women Bending with the Wind. The International Journal of Human Resource Management, 25(2), 144-166.
Ministry of Tourism. (2020, August 16). Tourism Investment. https://mt.gov.sa/en/Tourism Investment/Pages/TourismInvestment.aspx

Movono, A. \& Dahles, H. (2017). Female Empowerment and Tourism: A Focus on Businesses in a Fijian Village. Asia Pacific Journal of Tourism Research, 22(6), 681-692.

Najia, S., Priyanka, A., \& Saima, R. (2016). Women Empowerment and Economic Growth: Empirical Evidence from Saudi Arabia. Advances in Management and Applied Economics, 6(5), 1-5.

OECD. (2019). Women at Work in G20 Countries: Progress and Policy Action Since 2019. Paper prepared for the G20 Employment Working Group Saudi Arabia's G20 Presidency 2020. https:// www.ilo.org/wcmsp5/groups/public/---dgreports/--cabinet/documents/publication/wcms 756334.pdf

Omair, K. (2009). Arab Women Managers and Identity Formation through Clothing. Gender in Management: An International Journal, 24(6), 412431.

Oxaal, Z., \& Baden, S. (1997). Gender and Empowerment: Definitions, Approach and Implications for Policy (No. 40). Bridge, Institute of Development Studies.

Pelit, E., Öztürk, Y., \& Arslantürk, Y. (2011). The Effects of Employee Empowerment on Employee Job Satisfaction. International Journal of Contemporary Hospitality Management, 23(6), 784-802.

Ruohan, W., \& Xueyu, C. (2016, 01/01/). Gender Equality in the Workplace: The Effect of Gender Equality on Productivity Growth among the Chilean Manufacturers. The Journal of Developing Areas, 50(1), 257-274.

Saudi Gazette. (2019, March 25). Women's Role in Tourism Sector Set to Grow. https://saudigazette. com.sa/article/561982

Tamayo, S. G., Koettl, J., \& Rivera, N. (2021, April 21). The Spectacular Surge of the Saudi Female Labor Force. Brookings. https://www.brookings.edu/ blog/future-development/2021/04/21/thespectacular-surge-of-the-saudi-female-labor-force/

Zimmerman, M. A. (2000). Empowerment theory. In Handbook of community psychology (pp. 43-63). Springer, Boston, MA. 